\title{
Molecular investigation on the production of the pacific white shrimp (Litopenaeus vannamei) using diets based on biofloc meal
}

\begin{abstract}
In the present study, the effect of four dietary treatments with different inclusion levels of biofloc meal, that is $\mathrm{M}_{-} \mathrm{BFM}_{0 \%}, \mathrm{M} \_\mathrm{BFM}_{5 \%}, \mathrm{M}_{-} \mathrm{BFM}_{10 \%}$ and $\mathrm{M}_{-} \mathrm{BFM}_{20 \%}$ on the Litopenaeus vannamei growth performance, water quality, immune response, and antioxidant status were evaluated. Biofloc meal was prepared using molasses as a carbon source. Growth performances, immunological parameters were investigated in addition to pathological examination of shrimp and culture water using microbiological and molecular methods. The results showed that higher inclusion levels of biofloc meal in the diets, i.e., $\mathrm{M}_{-} \mathrm{BFM}_{10 \%}$ and $\mathrm{M} \mathrm{BFM}_{20}$ resulted in higher growth rate, final body weight, and lower feed conversion ratio $(\bar{p}<0.05)$. The biofloc meal enhanced phagocytic, lysozyme activities and antioxidative capacity in the L. vannamei provided with diet containing high inclusion levels of biofloc meal $\left(\mathrm{M}_{-} \mathrm{BFM}_{20} \%\right)(p<0.05)$. $16 \mathrm{~S}$ rRNA and random amplified polymorphic DNA (RAPD) were applied to track the changes in microbial evolution in the culture system. The results of $16 \mathrm{~S}$ rRNA and RAPD confirmed that the diets of the different culture system have effect on the evolution of the microbial communities in the culture system. In conclusion, higher inclusion levels of biofloc meal in the shrimp diet helps to improve growth performance, water quality and health of L. vannamei. The higher inclusion level of $\mathrm{M}_{-} \mathrm{BFM}_{20} \%$ is recommended.
\end{abstract}

Keywords: biofloc meal, alternatives, fish meal, fish oil, vibrio, nutritional value
Volume 8 Issue 6 - 2019

Mohamed E Megahed, Mohamed Fathi,
Abdelrhman Mohamed Abderhman
National Institute of Oceanography and Fisheries, Egypt

Correspondence: Mohamed E Megahed, National Institute of Oceanography and Fisheries (NIOF), Gulfs of Suez \& Aqaba's Branch, Egypt, Email aquageimprove@gmail.com

Received: November 20, 2019 | Published: November 28, 2019

\section{Introduction}

There is an increasing consumption in seafood because of the global expansion of the human population and consumer awareness regarding healthy seafood. This requires increase in the aquaculture production to meet this high demand. However, aquaculture still faces some major challenges such as the problems related to the environment and natural resource (fishmeal and fish oil), ${ }^{1}$ in addition to the transmission of aquatic animal diseases. ${ }^{1}$

Egypt aquaculture industry has been affected by disease outbreaks which led to economic losses to the farmers. The main farmed species in Egypt with the major production is Nile tilapia. This species has been suffering from mass mortalities starting from the last 5 years up to now, especially after the dissemination of Abbassa strain of Nile tilapia produced at World Fish Center, Egypt. The second species suffering mass mortalities due diseases outbreak is the marine shrimp. This dates back to 2010, when the General Authority for Fish Resources Development (GAFRD), approved the introduction of Fenneropenaeus indicus from UAE, as alternative to our native species Penaeus semisulcatus and Marsupenaeus japonicus which was the main farmed shrimp species in Egypt for long time ago dates back to 1980 s till 2009. The farming of introduced $F$. indicus was not successful after several trails of farming and mass mortalities starts from first year of farming (2010) till 2014. The GAFRD with some stakeholders has directed their direction to the introduction of another shrimp species Litopenaeus vannamei from National Aquaculture Group (NAQUA; Saudi Arabia) from 2015, 2016 and on going for 2017 to use broodstock from previous years in addition to new introduction of postlarvae of Litopenaeus vannamei from NAQUA. The production of 2015 and 2016 was not such encouraging on the economic level and the confirmation of EMS diseases and other shrimp viruses such as WSSV, IHHNV, YHV and TSV could be behind the low productivity and high mortality. In attempt to have control, biofloc technology has been used as a control production in shrimp farms. ${ }^{2-4}$

Biofloc technology (BFT) application in aquaculture offers a solution to the problem of suing fishmeal and fish oil in aquatic feeds. In BFT excess nutrient in aquaculture systems is converted into microbial biomass, which could be utilized for feeding culture aquatic species. ${ }^{2-4}$ To promote the heterotrophic bacteria growth, carbohydrate addition is carried out to adjust the $\mathrm{C} / \mathrm{N}$ ratio of the system to 10 or more..$^{2-5}$ This results in less feed protein needed and the amount of fishmeal per $\mathrm{kg}$ of fish produced can be reduced. Every month, samples of tank water were collected for studying the microbial communities using 16s rRNA and RAPD. A common microbiological technique, such as $16 \mathrm{~S}$ rRNA has been used for studying of bacterial communities in aquatic systems. ${ }^{6-8}$

The random amplified polymorphic DNA (RAPD) markers are useful, especially when there is no prior knowledge of DNA sequences to be examined and such polymorphisms follow Mendelian inheritance ${ }^{9}$. In the present study, we hypothesized that biofloc will not only improve water quality parameters but also contribute to fish feeding and affect the structure of microbial communities in culture water. To validate this hypothesis, we compared three feeds based on biofloc meal with feed without biofloc meal (control). The findings of this study will help to understand the impact of the biofloc meal based feeds on microbial communities in shrimp culture system, and examine the effect of using microbial biofloc meal as sustainable feed ingredient on the growth performance and health status of the shrimp L.vannamaei. 


\section{Materials and methods}

\section{Biofloc preparation}

This study was carried out at National Institute of Oceanography and Fisheries (NIOF), and Fish Research Center, Suez Canal University as a result of scientific collaboration through STDF funded project no. 5661. Biofloc reactor was prepared in 100L tank filled with seawater (35 ppt). The biofloc preparation tanks were fertilized with $25 \mathrm{mg} / \mathrm{L}$ of nitrogen $(\mathrm{N}), 3.6 \mathrm{mg} / \mathrm{L}$ phosphorous $(\mathrm{P})$, and $0.1 \mathrm{~mL} / \mathrm{L}$ of trace elements from fertilizers used in plant fertlization to stimulate biofloc production. following the procedure described in Megahed et al. ${ }^{4}$ The carbon source, molasses was added daily at $0.9 \mathrm{~mL} / \mathrm{L}$, to obtain a carnbon to nitrogen $(\mathrm{C} / \mathrm{N})$ ratio of 10 . The produced biofloc was continuously mixed using strong aeration. After 15 days, the biofloc was collected daily by sieving the water using nylon sieve $(100 \mu \mathrm{m})$, followed by. Drying at $60^{\circ} \mathrm{C}$ for $28 \mathrm{~h}$, and milled into fine powder for estimation the proximate and amino acid compositions (Table 1).

Table I Proximate composition $(\mathrm{g} / \mathrm{kg})$ and amino acids $(\mathrm{g} / \mathrm{kg})$ contents of biofloc with molasses as the carbon source

\begin{tabular}{ll}
\hline Proximate composition & Contents $(\mathbf{g} / \mathbf{k g})$ \\
\hline Moisture & 103 \\
Crude protein & 419 \\
Crude lipid & 26 \\
Crude fibre & 36 \\
Ash & 91 \\
Nitrogen free extract & 402 \\
Histidine & 4.73 \\
Threonine & 15.19 \\
Leucine & 18.26 \\
Lysine & 21.53 \\
Arginine & 11.01 \\
Valine & 16.18 \\
Isoleucine & 12.47 \\
Phenylalanine & 10.56 \\
Tryptophan & 2.68 \\
Methionine & 3.51 \\
Cysteine & 11.93 \\
Proline & 20.58 \\
Tyrosine & 10.43 \\
Aspartic acid & 7.28 \\
Glycine & 3 lanine \\
\hline
\end{tabular}

\section{Experimental diets}

This study included formulation of four isonitrogenous and isocaloric diets at four different levels of biofloc meal inclusion (Table 2). The proximate composition of the four diets is presented in Table 3 .

Table 2 Composition of experimental diets based on biofloc meal (M_BFM) used in the growth experiment

\begin{tabular}{lllll}
\hline $\begin{array}{l}\text { Ingredient (g/ } \\
\mathbf{k g})\end{array}$ & $\begin{array}{l}\mathbf{M}_{-} \\
\mathbf{B F M}_{\mathbf{0}} \%\end{array}$ & $\begin{array}{l}\mathbf{M}_{-} \\
\mathbf{B F M}_{5} \%\end{array}$ & $\begin{array}{l}\mathbf{M}_{-} \\
\mathbf{B F M}_{10} \%\end{array}$ & $\begin{array}{l}\mathbf{M}_{-} \\
\mathbf{B F M}_{20} \%\end{array}$ \\
\hline $\begin{array}{l}\text { Biofloc meal } \\
\text { M_BFM) }\end{array}$ & 0 & 50 & 100 & 200 \\
Fishmeal & 220 & 220 & 220 & 220 \\
Soybean meal & 350 & 320 & 290 & 230 \\
Wheat pollard & 320 & 300 & 280 & 240 \\
Fish oil & 60 & 60 & 60 & 60 \\
$\begin{array}{l}\text { Vitamin \& Mineral } \\
\text { Premix }\end{array}$ & 40 & 40 & 40 & 40 \\
CMC $^{\text {b }}$ & 10 & 10 & 10 & 10 \\
\hline
\end{tabular}

aVitamin and mineral mix (quantity/kg): Vitamin A, 20,00,000IU; Vitamin D3, 400,000 IU;Vitamin B2, 800mg;Vitamin C, 1000mg;Vitamin E, 300 unit;Vitamin K, 400mg;Vitamin B6, 400mg;Vitamin BI2, 2.4mg; Calcium Pantothenate, Ig; Nicotinamide, 4g; Choline Chloride, 60g; Mn, 10.8g; lodine, 0.4g; Fe, 3 g; Zn, 6g; $\mathrm{Cu}, 0.8 \mathrm{~g} ; \mathrm{Co}, 0.18 \mathrm{~g}$

${ }^{\circ} \mathrm{CMC}$ : Carboxymethyl cellulose

Table 3 Proximate (\%) and amino acids composition $(\mathrm{g} / \mathrm{kg})$ of the experimental diets in growth experiment

\begin{tabular}{lllll}
\hline $\begin{array}{l}\text { Proximate } \\
\text { composition (\%) }\end{array}$ & M_BFM $_{0} \%$ & $\begin{array}{l}\mathbf{M}_{-} \\
\mathbf{B F M}_{5} \%\end{array}$ & $\begin{array}{l}\mathbf{M}_{-} \\
\mathbf{B F M}_{10} \%\end{array}$ & $\begin{array}{l}\mathbf{M}_{-} \\
\mathbf{B F M}_{20} \%\end{array}$ \\
\hline Moisture & 6.53 & 7.86 & 7.96 & 6.22 \\
Crude protein & 37.21 & 36.83 & 35.15 & 36.24 \\
Crude lipid & 10.20 & 9.27 & 8.63 & 9.52 \\
Ash & 16.60 & 17.38 & 16.42 & 16.65 \\
Crude fiber & 3.05 & 3.62 & 2.54 & 2.63 \\
$\begin{array}{l}\text { Nitrogen free } \\
\text { extract (NFE)' }\end{array}$ & 32.94 & 32.90 & 37.26 & 34.96 \\
$\begin{array}{l}\text { Gross } \\
\text { energy (kcal/kg) }\end{array}$ & 3869 & 3814 & 3576 & 3735 \\
Histidine & 5.31 & 5.39 & 5.17 & 5.00 \\
Threonine & 9.83 & 10.20 & 10.19 & 10.87 \\
Leucine & 18.35 & 18.29 & 17.63 & 17.25 \\
Lysine & 13.71 & 13.99 & 14.53 & 14.22 \\
Arginine & 14.39 & 14.71 & 13.32 & 13.01 \\
Valine & 10.62 & 11.51 & 10.96 & 11.88 \\
Isoleucine & 10.11 & 09.98 & 09.95 & 09.37 \\
Phenylalanine & 11.09 & 11.32 & 11.01 & 11.01 \\
\hline
\end{tabular}




\begin{tabular}{|c|c|c|c|c|}
\hline $\begin{array}{l}\text { Proximate } \\
\text { composition (\%) }\end{array}$ & M_BFM $0 \%$ & $\begin{array}{l}\text { M_- }_{\text {BFM }_{5} \%}\end{array}$ & $\begin{array}{l}M_{-} \\
\text {BFM }_{10} \%\end{array}$ & $\begin{array}{l}\text { M_- }_{\text {BFM }_{20} \%}\end{array}$ \\
\hline Tryptophan & 1.62 & 1.85 & $\mathrm{I} .47$ & 1.03 \\
\hline Methionine & 4.23 & 4.08 & 4.30 & 4.75 \\
\hline Cysteine & 0.99 & 0.58 & 0.73 & 0.59 \\
\hline Proline & 14.23 & 13.98 & 13.79 & 12.96 \\
\hline Tyrosine & 02.99 & 3.52 & $3.4 I$ & 3.56 \\
\hline Aspartic acid & 22.96 & 21.37 & 20.02 & 19.08 \\
\hline Glycine & 18.02 & 17.91 & 16.53 & $|7.2|$ \\
\hline Alanine & 11.99 & $|2.3|$ & 12.04 & 13.94 \\
\hline Glutamate & 42.31 & 41.20 & 40.32 & 39.54 \\
\hline Serine & 11.23 & 11.05 & 11.75 & 11.82 \\
\hline
\end{tabular}

${ }^{\prime} \mathrm{NFE}(\%)=100-($ Crude protein+Ether extract+Ash+Fiber $)$

\section{Total Vibrio Count (TVC)}

Similar to method for estimation of TVC was described. ${ }^{4}$ Briefly, a series of 10-fold dilutions of water from each shrimp tank were made using sterile seawater as dilution blanks, and $0.1 \mathrm{ml}$ of each dilution was plated on agar plates by the spread plate method. Total Vibrio spp. count was estimated using thiosulfate-citrate-bile salt-sucrose (TCBS) agar (Difco) and incubated for $48 \mathrm{~h}$ at $28^{\circ} \mathrm{C}$.

\section{Immunological and biochemical analyses}

Haemolymph samples were taken after 56 days of the experimnetal period using a $1 \mathrm{ml}$ syringe containing $0.1 \mathrm{ml}$ of $3.8 \%$ trisodium citrate as anticoagulant. Immunological parameters such as, phagocytic and lysozyme activities were measured according to El-Boshy ME ${ }^{12}$ and Jiang $\mathrm{CM}^{13}$ respectively. Lipid peroxidation in the shrimp body was estimated by using thiobarbituric acid method by measuring malondialdehyde (MDA) as the marker. ${ }^{14}$ Superoxide dismutase (SOD) activity in shrimp body was estimated according to Misra and Fridovich. ${ }^{15}$

\section{Sample collection and bacterial genomic DNA extraction}

For genetic study of the biofloc, water samples were collected from each treatment followed by sequential filtration using $8-\mu \mathrm{m}$ qualitative filter paper, followed by filtration through polycarbonate membranes $(0.22-\mu \mathrm{m})$ (Merck, Germany). $1.5 \pm 0.03 \mathrm{~g}$, was randomly assigned to 12 plastic boxes previously filled with $20 \mathrm{~L}$ of seawater (35 ppt) at a density of 15 shrimp per tank. The shrimp was fed four times daily for 56 days. Sampling was performed every 15 days to monitor growth and survival of the shrimp. Growth performance (Table 4) was calculated as average daily gain (ADG), feed conversion ratio (FCR) and Survival rate (SR \%) were calculated as follows:

$\operatorname{ADG}\left(\mathrm{g} \mathrm{day}^{-1}\right)=($ final wet weight-initial wet eight $) /$ days of culture;

$\mathrm{FCR}=$ total feed fed $(\mathrm{g}) /$ total wet weight gain $(\mathrm{g})$; and

Survival rate $(\mathrm{SR} \%)=($ number at harvestX100)/number at stocking.

After 56 days, all shrimp were collected and weighed. Five shrimp were used for haemolymph sampling, and preserved at $-20^{\circ} \mathrm{C}$ for further analyses.

\section{Physicochemical analysis}

The proximate composition of biofloc samples were according to Megahed and Mohamed ${ }^{3}$ and Megahed et al. ${ }^{4}$ Gross energy (GE), Kcal was calculated by multiplying CPX5.65+fatX9.45+Carbohydrate $\times 4$, according to Jobling M. ${ }^{10}$ Amino acids composition was analyzed at a certified laboratory (Regional Center for Food \& Feed (RCFF), Agricultural Research Center, Egypt).

\section{Water quality}

During the experimental period, water exchange was done at each treatment at a level of $15 \%$ every 3 days. Temperature $\left({ }^{\circ} \mathrm{C}\right), \mathrm{pH}$ and dissolved oxygen (DO) concentration were measured daily by using a YSI 556MPS meter (Yellow Spring Instrument Co., OH, USA). Whereas, total ammoniacal nitrogen (TAN) was determined weekly according to APHA. ${ }^{11}$

\section{PCR analysis}

Genomic DNA was extracted from the filtrates of each treatment using the bacterial xpress nucleic acid extraction kit (Merck, Germany). The V3 variable regions of bacterial 16S rRNA genes were amplified by PCR using the primer pair P3(5'-GCCCGCCGC GCGCGGCGGGCGGGGCGGGGGCACGGGGGGCCTACGGG AGGCAGCAG-3') and P2 (5'-ATTACCGCGGCTGCTGG-3') as described previously. ${ }^{16}$ The PCR reaction was performed in a $25 \mu \mathrm{L}$ as described previously, ${ }^{17}$ using PCR major cycler (Major Science, USA). $10 \mu \mathrm{L}$ PCR products were analyzed by $1.5 \%$ agarose gel and DNA band visualized by Safe Blue system (Major Science, USA). For RAPD technique, a three primers of 10-mer RAPD oligonucleotides (Operon Technologies, Inc.) A). 0PA03 AGTCAGCCAC; B) OPA17 GACCGCTTGT and C) OPB08 GTCCACACGG, were tested.

\section{Statistical analysis}

Statistical analysis was performed using SPlus v 8.0 for Windows (Insightful Corp.). One- way ANOVA followed by Tukey's test was employed to test the significant differences between treatments. Significance different was considered when $P$-value $<0.05$. Data were subsequently subjected to regression analyses (linear and quadratic) where the dietary biofloc meal level served as the independent variable. The second-order polynomial regression model was used to estimate the maximum dietary addition of biofloc meal for shrimp on the basis of final shrimp mean body weight. ${ }^{18}$ For RAPD analysis was performed using the NTSYS-PC version 1.70 (Numerical Taxonomy and Multivariate Analysis System) computer program. ${ }^{19}$ The presence and absence of fragments were scored as 1 or 0 , respectively. Pairwise comparison of banding patterns was evaluated using the Jaccard 
coefficient. ${ }^{20}$ The genetic variability was expressed by mean allele frequency ${ }^{21}$ and by mean heterozygosity ${ }^{22}$ and cluster analysis, using the UPGMA method (unweighted pair-group method with arithmetical averages) ${ }^{23}$

\section{Results}

\section{Shrimp growth performance}

The increase in inclusion level of biofloc meal resulted in improvement in shrimp growth performance $(p<0.05)$. (Table 4). The FCR improved with the increase of biofloc meal levels in the diets $(p<0.05)$. The biofloc meal at inclsion level of $20 \%$ resulted in a abetter improvement in the FCR and growth of the shrimp as compared with that of the control and other treatments $(p<0.05)$.

\section{Total PUFAs content in the shrimp body}

The fatty acid composition of the shrimp body is presented in Table 5. The shrimp in the diets based on biofloc meal showed high total n-3 and n-6 PUFAs than the control diet. The shrimp diets based on biofloc meals achieved higher content of both total n-3 PUFAs and total n-6 PUFAs, compared to the control diet without biofloc meal $(p<0.05)$. The diet based on highest inclusion level of biofloc meal M_BFM ${ }_{20} \%$ was the highest in both total $\mathrm{n}-3$ PUFAs $(10.57 \mathrm{mg} / \mathrm{g}$ DW) and total n-6 PUFAs $(7.98 \mathrm{mg} / \mathrm{g} \mathrm{DW})(p<0.05)$.

Table 4 Growth performance and feed utilization of shrimp L.vanamaei fed with diets containing graded levels of biofloc meal (M_BFM_\%, M_BFM $\%$, M_BFM $10 \%$ and $M_{-} \mathrm{BFM}_{20} \%$ ) after 56 days of experimental period

\begin{tabular}{|c|c|c|c|c|c|c|c|}
\hline & \multicolumn{4}{|c|}{ Inclusion levels of biofloc meal } & \multirow{2}{*}{ SEM } & \multicolumn{2}{|c|}{ Regression $\left(\mathbf{P}, \mathbf{r}^{2}\right)$} \\
\hline & M_BFM ${ }_{0} \%$ & M_BFM $\%$ & M_BFM $_{10} \%$ & M_BFM $20 \%$ & & Linear & Quadratic \\
\hline Initial body weight (g) & $1.5 \pm 0.3$ & $1.5 \pm 0.5$ & $1.5 \pm 0.5$ & $1.5 \pm 0.5$ & & & \\
\hline Final body weight (g) & $14.42^{c}$ & $16.18^{b}$ & $16.83^{\mathrm{b}}$ & $17.94^{\mathrm{a}}$ & 0.26 & $0.000,0.598$ & $0.00 \mathrm{I}, 0.363$ \\
\hline ADG $\left(\mathrm{g} \mathrm{day}^{-1}\right)$ & $0.23^{b}$ & $0.26^{\mathrm{a}}$ & $0.27^{\mathrm{a}}$ & $0.29^{a}$ & 13 & $0.001,0.659$ & $0.001,0.692$ \\
\hline FCR & $1.98^{\mathrm{a}}$ & $1.5 \mathrm{I}^{\mathrm{b}}$ & $1.29^{c}$ & $1.20^{c}$ & 0.02 & $0.012,0.451$ & $0.01 \mathrm{I}, 0.5 \mathrm{II}$ \\
\hline SR (\%) & $48.52^{d}$ & $62.31^{c}$ & $73.95^{\mathrm{b}}$ & $83.4 \mathrm{I}^{\mathrm{a}}$ & 0.01 & $0.016,0.370$ & $0.011,0.257$ \\
\hline
\end{tabular}

Different letters following mean values in the same row indicate significant differences $(p<0.05)$. SEM=pooled standard error of means

Table 5 Fatty acids profile of shrimp fed with biofloc meal

\begin{tabular}{lllll}
\hline Fatty acid (mg/gDW) & Diets & & & \\
\hline & M_BFM $\%^{\circ}$ & M_BFM $_{5} \%$ & M_BFM $_{10} \%$ & M_BFM $_{20} \%$ \\
\hline Total n-3 PUFAs & $6.9^{\mathrm{d}}$ & $8.25^{\mathrm{c}}$ & $9.42^{\mathrm{b}}$ & $10.57^{\mathrm{a}}$ \\
Total n-6 PUFAs & $3.38^{\mathrm{d}}$ & $5.21^{\mathrm{c}}$ & $6.28^{\mathrm{b}}$ & $7.98^{\mathrm{a}}$ \\
\hline
\end{tabular}

Different letters following mean values in the same row indicate significant differences $(p<0.05)$

\section{Shrimp abnormality}

During this experiment, some abnormalities were observed in shrimps particularly those fed diet without biofloc meal (Figure 1). The most obvious abnormality was observed in the tail part of the shrimp with a change in the colour indicating abnormal clinical signs.

\section{Water quality}

The average $\mathrm{T}^{\circ} \mathrm{C}, \mathrm{pH}, \mathrm{DO}$, and TAN during the experiment are presented in Table 6. TAN and DO of the water in the shrimp rearing tanks were significantly different $(p<0.05)$. The $\mathrm{M}_{-} \mathrm{BFM}_{10} \%$ and $\mathrm{M}_{-}$ $\mathrm{BFM}_{20} \%$ treatments were the highest $\mathrm{DO}$ and lower TAN compared to $\mathrm{M}_{-} \mathrm{BFM}_{5} \%$ and $\mathrm{M}_{-} \mathrm{BFM}_{0} \%$.

\section{Immune parameters}

Shrimp immune response at the diffeent feeding treatmnets against was evaluated by phagocytic and lysozyme activity (Table 7). Phagocytic activity was increased with the increase in biofloc meal inclusion levels $(p<0.05)$. The highest levels of phagocytic and lysozyme activities were observed in the shrimp fed with $\mathrm{M}_{-}$ $\mathrm{BFM}_{20}$ diet. There were no significant differences in SOD activity $(p>0.05)$. The concentrations of MDA in diets with biofloc meal were significantly lower than control diet $(p<0.05)$.

\section{Total Vibrio Count (TVC)}

In order to verify the cause of shrimp abnormalities observed in this study, which was likely caused by Vibrio, total vibrio count (TVC) in the shrimp culture systems was conducted. There was no significant difference $(p>0.05)$ in TVC in the water from culture systems of the diets based on biofloc meal (Table 8 ). The highest TVC was determined in the control, $6.8 \times 10^{3} \mathrm{CFU} / \mathrm{mL}$.

\section{Pathogenic bacteria in the shrimp rearing tanks}

A number of pathogenic bacteria were detected in the rearing water of the different treatments: Aeromonas hydrophila, Aeromonas caviae, Mycobacterium marinum, and Vibrio spp. They were all higher count at $\mathrm{M}_{-} \mathrm{BFM}_{0} \%$ treatment compared to the rest of treatments and control. The bacterial species, A. caviae and M. marinum was detected in the culture system, which are considered a major pathogen in shrimp aquaculture, in addition to Vibrio spp. (Table 9). The result of $16 \mathrm{~s}$ rRNA is presented in Figures $2 \& 3$. 
Table 6 Water quality parameters during growth experiments

\begin{tabular}{lllll}
\hline & Temperature $\left({ }^{\circ} \mathrm{C}\right)$ & $\mathbf{p H}$ & $\begin{array}{l}\text { Dissolved oxygen } \\
(\mathrm{DO})(\mathbf{m g} / \mathrm{L})\end{array}$ & $\begin{array}{l}\text { Total ammonia } \\
\text { nitrogen (TAN) mg/L) }\end{array}$ \\
\hline M_BFM $\%$ & $29.8^{\mathrm{a}}$ & $7.85^{\mathrm{a}}$ & $5.98^{\mathrm{c}}$ & $0.25^{\mathrm{a}}$ \\
M_BFM $\%$ & $29.6^{\mathrm{a}}$ & $7.82^{\mathrm{a}}$ & $7.00^{\mathrm{b}}$ & $0.10^{\mathrm{b}}$ \\
M_BFM $\%$ & $29.9^{\mathrm{a}}$ & $7.80^{\mathrm{a}}$ & $8.99^{\mathrm{a}}$ & $0.1 \mathrm{I}^{\mathrm{b}}$ \\
M_BFM $_{20} \%$ & $29.7^{\mathrm{a}}$ & $7.80^{\mathrm{a}}$ & $8.90^{\mathrm{a}}$ & $0.1 \mathrm{I}^{\mathrm{b}}$ \\
\hline
\end{tabular}

Different letters following mean values in the same row indicate significant differences $(p<0.05)$

Table 7 Immune parameters of shrimp L. vanaemai fed with diets containing different levels of biofloc meal (M_BFM_\%, M_BFM $\%$, M_BFM $\%$ and $M_{10}$ BFM $\left.{ }_{20} \%\right)$ after 56 days of experimental period

\begin{tabular}{|c|c|c|c|c|c|c|c|}
\hline & \multicolumn{4}{|c|}{ Inclusion levels of biofloc meal } & \multirow{2}{*}{ SEM } & \multicolumn{2}{|c|}{ Regression (P, $\left.\mathbf{r}^{2}\right)$} \\
\hline & M_BFM $\%$ & M_BFM $\%$ & M_BFM $10 \%$ & M_BFM ${ }_{20} \%$ & & Linear & Quadratic \\
\hline Phagocytic activity (\%) & $40.3^{b}$ & $43.6^{\mathrm{ab}}$ & $45.2^{\mathrm{a}}$ & $46.0^{\mathrm{a}}$ & 1.27 & $\begin{array}{l}0.022 \\
0.357\end{array}$ & $0.001,0.874$ \\
\hline Lysozyme activity (U/ml) & $2.59^{c}$ & $4.98^{b}$ & $6.46^{a}$ & $6.99^{\mathrm{a}}$ & 0.69 & $\begin{array}{l}0.001 \\
0.823\end{array}$ & $0.000,0.935$ \\
\hline $\begin{array}{l}\text { Superoxide dismutase (abs/ } \\
\mathrm{ml} \text { ) }\end{array}$ & $11.89^{\mathrm{a}}$ & $11.92^{\mathrm{a}}$ & $12.14^{\mathrm{a}}$ & $12.26^{\mathrm{a}}$ & 0.33 & NS ${ }^{\prime}$ & NS \\
\hline Malondialdehyde $(\mu \mathrm{mol} / \mathrm{L})$ & $47.31^{\mathrm{a}}$ & $15.42^{b}$ & $15.25^{b}$ & $15.58^{b}$ & 4.54 & $\begin{array}{l}0.000 \\
0.356\end{array}$ & $0.006,0.682$ \\
\hline
\end{tabular}

Different letters following mean values in the same row indicate significant differences $(p<0.05)$. SEM=pooled standard error of means NS=not significant

Table 8 Average TVC in water in the shrimp rearing tanks

\begin{tabular}{lllll}
\hline & M_BFM & M_BFM $\%$ & M_BFM $\%$ & M_BFM \\
\hline Average TVC $(\mathrm{CFU} / \mathrm{mL})$ & $6.8 \times 10^{3}\left(3.8 \times 10^{2}\right)^{\mathrm{a}}$ & $2.2 \times 10^{2}\left(5.3 \times 10^{1}\right)^{\mathrm{b}}$ & $1.5 \times 10^{3}\left(1.9 \times 10^{2}\right)^{\mathrm{c}}$ & $1.1 \times 10^{3}\left(9.2 \times 10^{1}\right)^{\mathrm{c}}$
\end{tabular}

Mean values (Standard deviation) in same row with a different superscript differ significantly $(p<0.05)$

Table 9 Bacterial pathogens identified in the shrimp rearing tanks

\begin{tabular}{|c|c|c|c|c|}
\hline \multirow[t]{2}{*}{ Pathogen } & \multicolumn{4}{|c|}{ Treatments* } \\
\hline & M_BFM $\%$ & M_BFM $\%$ & M_BFM $10 \%$ & M_BFM ${ }_{20} \%$ \\
\hline Aeromonas hydrophila & +++ & + & - & - \\
\hline Aeromonas caviae & - & + & - & - \\
\hline Mycobacterium marinum & +++ & + & - & - \\
\hline Vibrio spp. & +++ & + & - & - \\
\hline
\end{tabular}

*Relative abundance

\section{RAPD analyses}

The RAPD profiles were depicted in Figure 4. The random primers used in this study produced several banding patterns among the different water groups tested. The banding profile showing genetic variation between the different treatments. Unbiased genetic distances and genetic similarity ${ }^{24}$ between the different treatments are given in Figure 5. The genetic identity between the different water samples was using detected using primer 0PA03 AGTCAGCCAC and OPA 17 GACCGCTTGT. 


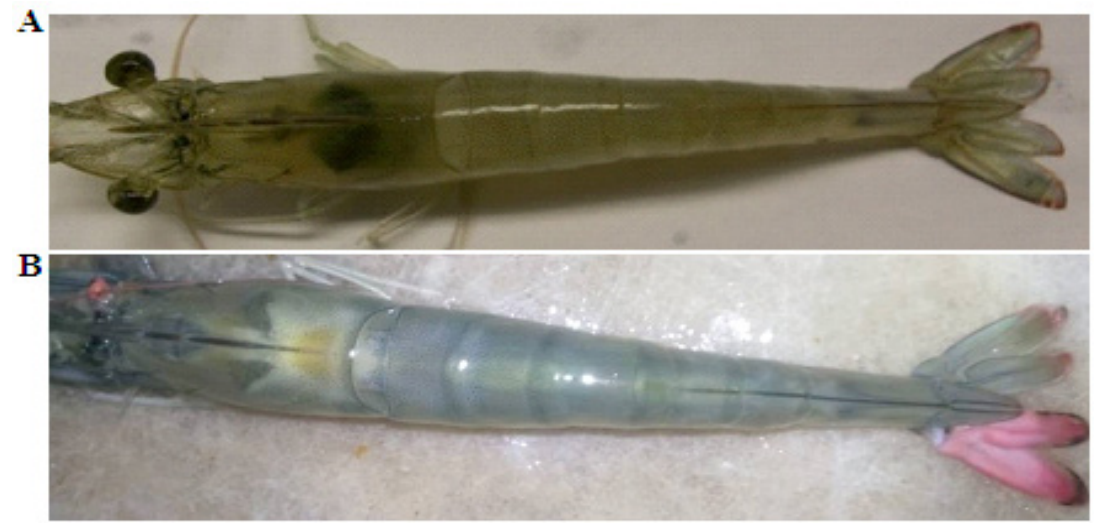

Figure I (A) Shrimp with normal tail. (B) Shrimp with abnormal tail and abnormal color.

A $\quad$ B

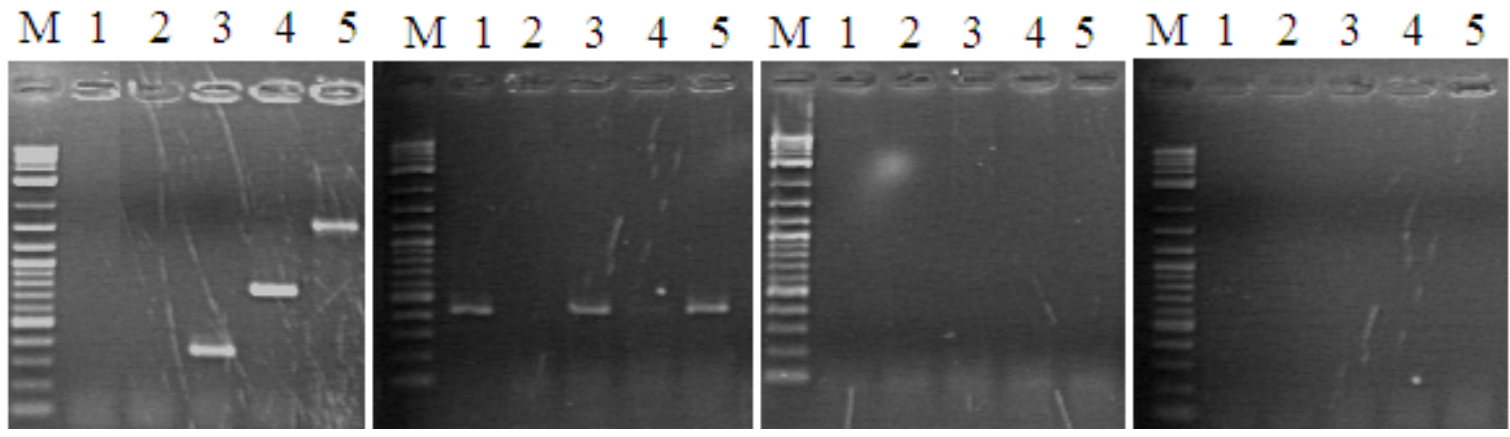

Figure $2 \mathrm{Gel}$ electrophoresis of $16 \mathrm{~s}$ rRNA of water samples from the shrimp rearing tanks of the different experimental diets from week 2 to week 5 . (A) Diet M_BFM $\%$; M: molecular weight marker; lane I: sterile $\mathrm{H}_{2} \mathrm{O}$; lanes 2-5: water samples (week 2 -5). (B) Diet $\mathrm{M}_{-} \mathrm{BFM}$ \%; $\mathrm{M}$ : molecular weight marker; lane I: sterile $\mathrm{H}_{2} \mathrm{O}$; lanes 2-5: water samples (week $2-5$ ). (C) Diet $\mathrm{M}_{3} \mathrm{BFM}$ \%; $\mathrm{M}$ : molecular weight marker; lane I: sterile $\mathrm{H}_{2} \mathrm{O}$; lanes 2-5: water samples (week $2-5$ ). (D) Diet M_BFM 20 ; M: molecular weight marker; lane I: sterile $\mathrm{H}_{2} \mathrm{O}$; lanes 2-5: water samples (week $2-5$ ).

A

B

$\mathrm{C}$

$\mathrm{D}$

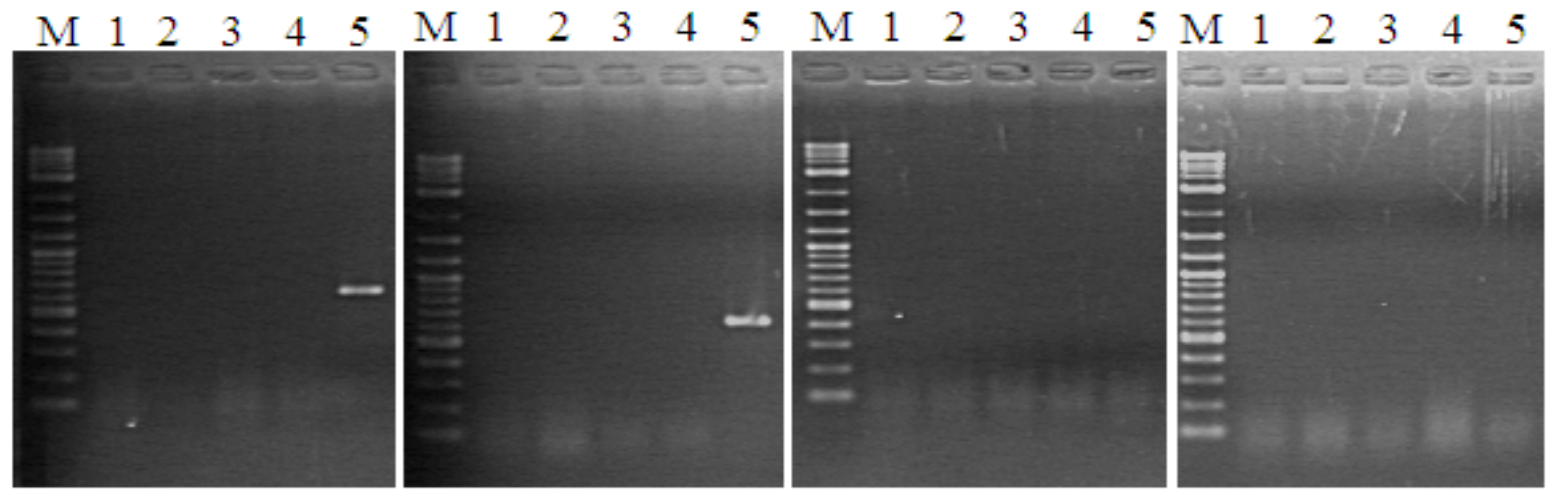

Figure $3 \mathrm{Gel}$ electrophoresis of $16 \mathrm{~s}$ rRNA of water samples from the shrimp rearing tanks of the different experimental diets from week 6 to week 8 . (A) Diet M_BFM0\%; M: molecular weight marker; lanes I-2: sterile H2O; lanes 3-5: water samples (week 6-8). (B) Diet M_BFM5\%; M: molecular weight marker; lanes I-2: sterile $\mathrm{H} 2 \mathrm{O}$; lanes 3-5: water samples (week 6-8). B). (C) Diet M BFMI0\%; M: molecular weight marker; lanes I-2: sterile $\mathrm{H}_{2} \mathrm{O}$; lanes 3-5: water samples (week 6-8). B). (D) Diet M_BFM20\%; M: molecular weight marker; lanes I-2: sterile H2O; lanes 3-5: water samples (week 6-8). B). 
A

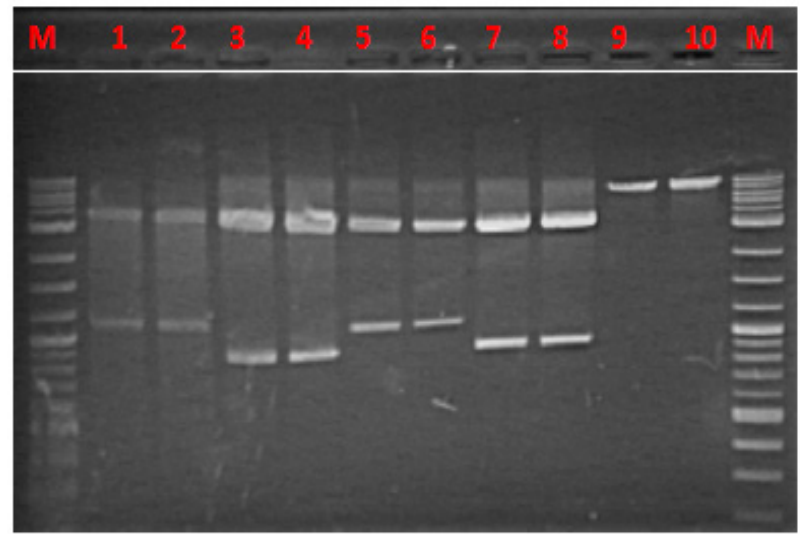

B

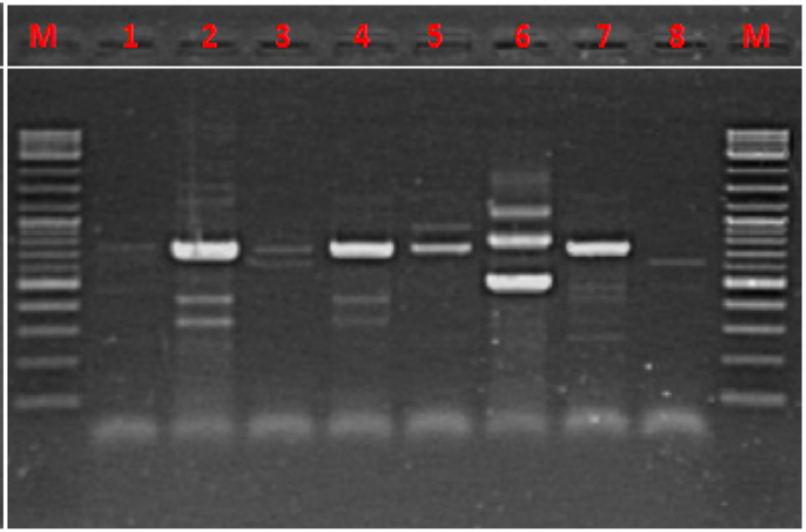

Figure 4 RAPD patterns of the water groups tested using random primers (A). OPA03 AGTCAGCCAC: lanes I- 2: water samples from diet M_BFM\%; lanes 3-4: diet M_BFM $\%$; lanes 5-6: diet M_BFM $10 \%$; lanes 7-8: Diet M_BFM $_{20} \%$, and lanes 9-I0: water inoculums from tilapia fish farm. (B) OPA I7 GACCGCTTGT: lanes I, 3, 5 and 8: boiled water samples from diets $M_{-}$BFM $\%$, $M_{-}$BFM 5 , M_BFM 10 , and $M_{-}$BFM 20 , respectively. Lanes 2, 4, 6, and 7: water samples from diets M_BFM $\%$, M_BFM $\%$, M_BFM 10 , and M_BFM $_{20} \%$, respectively.

A

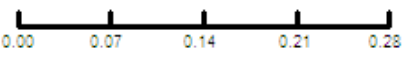

B

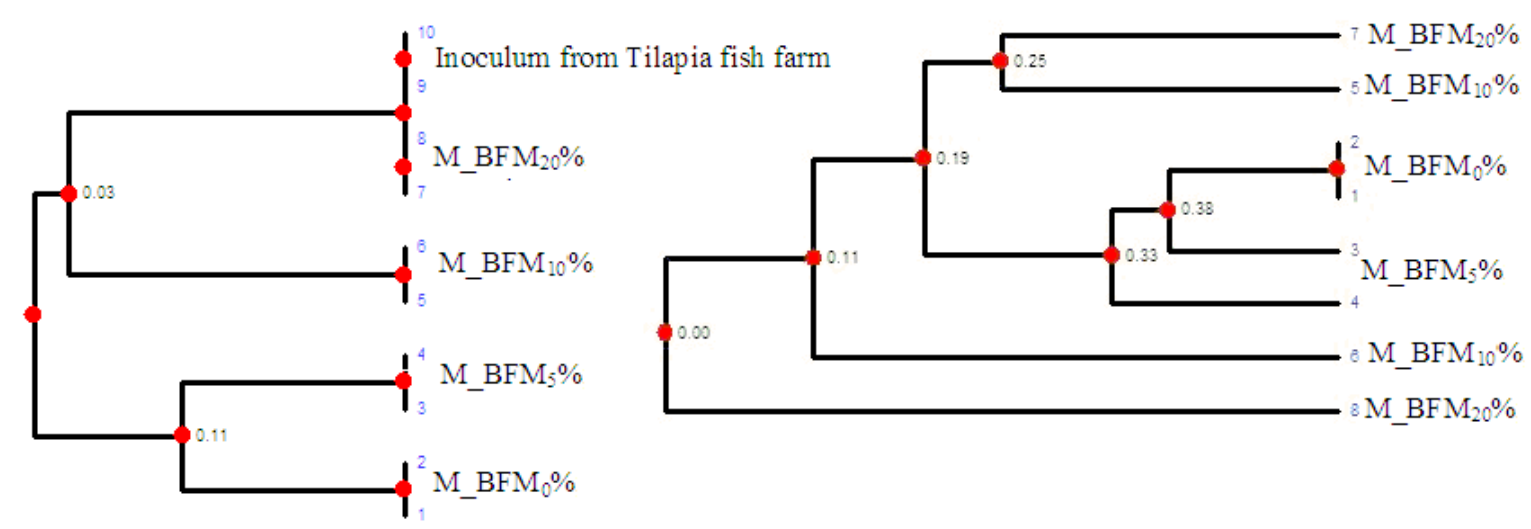

Figure 5 Dendogram showing the genetic relationships among the different water samples from the different diets used in the shrimp feeding experiment using random primers (A). OPA03 AGTCAGCCAC and (B) OPAI7 GACCGCTTGT. Similarity matrix calculated by Jaccard coefficient.

\section{Discussion}

During the experimental period, we observed that the shrimp in all treatments were able to consume the diets based on biofloc meal, as the color of the digestive tract with diets based on biofloc meal revealed brownish digestive tracts, similar to the colors of the biofloc meal. The highest average survival was observed in the $\mathrm{M}_{-} \mathrm{BFM}_{20} \%$, treatment. The shrimp performance in this study was affected by the culture system, and this is in line with previous studies, ${ }^{25-27}$ nutrition ${ }^{28}$ and health status. ${ }^{29-31}$ Previous study ${ }^{32}$ reported that $32 \%$ protein diet gave a better growth of juvenile and subadult $L$. vanname $i$ as compared to diets with a lower (16\%) and higher $(42 \%)$ protein content.

Disease infection may cause the cultured animal to lose their feeding appetite. Apart from some abnormalities on the shrimp tails, there was no other visual disease symptom observed. However, further investigation for disease diagnosis was carried out during this experiment. The difference of TVC between treatments was significant, and the control contained higher presumptive Vibrio concentrations than all other treatments, in which the shrimp abnormalities were found. Bang et al. ${ }^{33}$ noted that the presumptive Vibrio in water of white shrimp L.vannamei ponds treated with probiotics was significantly lower $\left(4.37 \times 10^{2} \mathrm{CFU} / \mathrm{mL}\right)$ than the untreated control ponds $(2.09$ $\mathrm{x} 10^{3} \mathrm{CFU} / \mathrm{mL}$ ). The present study clearly showed that the utilization of molasses as crbon source resulted in production of biofloc with high protein and amino acids concentrations. This demonstrated the effect of the carbon source on the nutritional quality of the biofloc produced and this is in line with previous studies that carbon source significantly affected biofloc contents of protein, lipid and other nutrients. ${ }^{2-4,32,35}$

The shrimp growth performance were improved with the increase in inclusion level of the biofloc meal in the diets. The unique attractability feature of the biofloc meal is due to its content of free amino acids such as alanine and glycine and proline, this is in line with previous results. ${ }^{4,36}$ The biofloc meal was demonstrated to 
support the growth in some other shrimp species including Penaeus monodon, ${ }^{37}$ L.vannamei, ${ }^{38}$ Penaeus semisulcatus, ${ }^{2}$ indian white shrip Fenneropenaeuss indicus. ${ }^{3,4}$ The biofloc meal may played as health enhancer for the shrimp role by the higher bioavailability of nutrients, and bioactive molecules, which is well known for its ability to improve the immune response and act as antioxidant. ${ }^{4}$

The shrimp fed with diets based on higher inclusion levels of biofloc meal showed higher immune response in terms of phagocytic and lysozyme activities than shrimp fed with control diet (M $\left.\mathrm{BFM}_{0} \%\right){ }^{37,39}$ The highest immune response of shrimp were observed at $20 \%$ inclusion level of the biofloc meal (M BFM2 \%). The shrimp fed with a diets based on biofloc meal showed lower MDA concentration. This confirms that shrimp fed with diets based on biofloc meal has a lower lipid peroxidation compared with shrimp fed with control diet. The shrimp fed with diet based on biofloc meal has shown higher immune response conpared with control without biofloc meal. These results are in line with previous studies by Ju et al. ${ }^{36}$ and Megahed et al., ${ }^{4}$ who demonstrated that biofloc contributes with bioactive compounds such as carotenoids, phytosterols, and antibacterial compounds such as B-1,3-glucan, lipopolysaccharides and peptidoglycan produced from the digestion of biofloc meal in the shrimp digestive tract. These compounds has stimulating efefct on the non-specific immune system of the shrimp. ${ }^{40,4}$

This study demonstrated that of biofloc meal has influence on the composition of the bacterial community in the culture system of $L$. vannamei, by observing microbial composition in the water samples in the culture tanks over the experimental period, and was characterized by bacteriology and $16 \mathrm{~S}$ rDNA. The highest bacterial abundance observed in the system was for bacterial species of Aeromonas hydrophila, Aeromonas caviae, and Vibrio spp. There is substantial shift in bacterial population in the culture systems based on diet contains different levels of biofloc. The biofloc meal sometimes may act as antimicrobial compounds, which clearly shown by negative $16 \mathrm{~S}$ rRNA - PCR results in some treatments based on biofloc meal. The results of this study may offer a tool for the control of shrimp pathogens in the culture system, particularly pathogens mediated by the feed contents.

\section{Conclusions}

The present study demonstrated that biofloc meal could be used as a raw material for preparation of shrimp diet. In addition to the improvement in shrimp growth and health. A biofloc meal inclusion level of $20 \%$ (Diet M_BFM $20 \%$ ), is recommended as it has resulted in the highest growth performance and improved shrimp health. The 16S rRNA and RAPD was used as a tool to track the change of microbial communities in the culture system. The results demonstarted that biofloc meal has significant effect on the evolution of microbal orgnaimsm in the culture system. RAPD technique allowed for illustration of the difference in the microrganims in the culture sytems of the different deiet, with further studies may facilitate identification of water microbes by multiplex analysis.

\section{Acknowledgment and funding}

This work was supported by Science \& Technology Development Fund (STDF), Egypt under grants no 5661.

\section{Conflicts of interest}

The author declares that there are no conflicts of interest

\section{References}

1. FAO. The state of world fisheries and aquaculture 2006. FAO. 2007;180 p.

2. Megahed ME. The effect of microbial biofloc on water quality, survival and growth of the green tiger shrimp Penaeus semisulcatus fed with different crude protein levels. Arab J Aqua. 2010;5(2):119-142.

3. Megahed ME, Mohamed K. Sustainable growth of shrimp aquaculture through biofloc production as alternative to fishmeal in shrimp feeds. Journal of Agricultural Science. 2014;6(6):176-188.

4. Megahed ME, Elmesiry G, Ellithy A, et al. Genetic, nutritional and pathological investigations on the effect of feeding low protein diet and biofloc on growth performance, survival and disease prevention of Indian white shrimp Fenneropenaeus indicus. Aquaculture International. 2018;26(2):589-615.

5. Azim ME.; Little DC, Bron JE. Microbial protein production in activated suspension tanks manipulating $\mathrm{C} / \mathrm{N}$ ratio in feed and implications for fish culture. Bioresour Technol. 2007;99(9):3590-3599.

6. Cottrell MT, Kirchman DL. Community composition of marine bacterioplankton determined by $16 \mathrm{~S}$ rRNA gene clone libraries and fluorescence in situ hybridization. Appl Environ Microbiol. 2000;66(12):5116-5122.

7. Revetta RP, Matlib RS, Santo Domingo JW.16S rRNA gene sequence analysis of drinking water using RNA and DNA extracts as targets for clone library development. Curr microbiol. 2011;63(1):50-59.

8. Bekaert K, Devriese L, Maes S, et al. Characterization of the dominan bacterial communities during storage of Norway lobster and Norway lobster tails (Nephrops norvegicus) based on 16S rDNA analysis by PCR-DGGE. Food microbiology. 2015;46:132-138.

9. Hadrys H, Balick M, Schierwater B. Applications of random amplified polymorphic DNA (RAPD) in molecular ecology. Mol Ecol. 1992;1(1):55-63.

10. Jobling M. A short review and critique of methodology used in fish growth and nutrition studies. J Fish Biol. 1983;23(6):685-703.

11. APHA. Standard Methods for the Examination of the Water and Wastewater. 22nd ed. Washington, DC: American Public Health Association. 2012; 724 p.

12. El-Boshy ME, ElAshram AM, Abdelhamid FM, et al. Immunomodulatory effect of dietary Saccharomyces cereviciae, $\beta$-glucan and laminaran in mercuric chloride treated Nile tilapia (Oreochromis niloticus) and experimentally infected with Aeromonas hydrophila. Fish and Shellfish Immunology. 2010;28(5-6):802-808.

13. Jiang CM, Wang MC, Chang WH, et al. Isolation of lysozyme from hen egg albumen by alcohol-insoluble cross-linked pea pod solid ionexchange chromatography. Journal of Food Science. 2001;66(8):10891092.

14. Giannenas I, Triantafillou E, Stavrakakis S, et al. Assessment of dietary supplementation with carvacrol or thymol containing feed additives on performance, intestinal microbiota and antioxidant status of rainbow trout (Oncorhynchus mykiss). Aquaculture. 2012;350-353:26-32.

15. Misra HP, Fridovich I. The role of superoxide anion in the autoxidation of epinephrine and a simple assay for superoxide dismutase. J Biol Chem. 1972;247:3170-3175.

16. Muyer G, de Waal EC, Uitterlinden AG. Profiling of complex microbial populations by denaturing gradient gel electrophoresis analysis of polymerase chain reaction-amplified genes coding for 16S Rrna. Appl. Environ Microbiol. 1993;59(3):695-700

17. Zhang $\mathrm{Y}$, Zhang $\mathrm{XO}$, Chen $\mathrm{T}$, et al. Circular intronic long noncoding RNAs. Mol Cell. 2013;51(6):792-806 
18. Wang C, Pan L, Zhang K, et al. Effects of different carbon sources addition on nutrition composition and extracellular enzymes activity of biofloc, and digestive enzymes activity and growth performance of Litopenaeus vannamei in zeroex changed culture tanks. Aquaculture Research. 2016;47:3307-3318.

19. Rohlf FJ. NTSYS-PC: Numerical taxonomy and multivariate analysis system. Applied Biostatistics. Steauket, New York 1993.

20. Jaccard, P. Étude comparative de la distribution florale dans une portion des Alpes et des Jura. Bulletin de la Société Vaudoise des Sciences Naturelles. 1901;37:547-579.

21. Jeffreys AJ, Morton DB. DNA fingerprints of dogs and cats. Anim Genet. 1987;18(1):1-15.

22. Georges M, Lequarre AS, Castelli M, et al. DNA fingerprinting in domestic animals using four different minisatellite probes. Cytogenet Cell Genet. 1988;47:127-131.

23. Sneath PHA. Sokal RR. Numerical Taxonomy. WH Freeman editor, San Francisco, California; 1973;573 p.

24. Nei M. Estimation of average heterozygosity and genetic distance from a small number of individuals. Genetics. 1987;89(3):583-590.

25. Tacon AGJ. The Nutrition and Feeding of Farmed Fish and Shrimp-A Training Manual. The Essential Nutrients. Food and Agriculture Organization of the United Nations. GCP/RLA/075/ITA, Brazil. $1987 ; 117 \mathrm{p}$

26. Williams AS, Davis DA, Arnold CR. Density- dependent growth and survival of Penaeus setiferus and Penaeus vanamei in semiclosed recirculation system. Journal of the World Aquaculture Society.1996;27:107-112.

27. Tacon AGJ, Cody JJ, Conquest LD, et al. Effect of culture system on the nutrition and growth performance of Pacific white shrimp Litopenaeus vannamei (Boone) fed different diets. Aquaculture Nutrition. 2002;8(2):121-137.

28. Chen J, Ren Y, Wang G, et al. Dietary supplementation of biofloc influences growth performance, physiological stress, antioxidant status and immune response of juvenile sea cucumber Apostichopus japonicus (Selenka). Fish \& Shellfish Immunology. 2018;72:143-152.

29. Rengpipat S, Phianphak, W, Piyatiratitivorakul S, et al. Effects of a probiotic bacterium on black tiger shrimp Penaeus monodon survival and growth. Aquaculture.1998;167(3-4):301-313.
30. Argue BJ, Arce SM, Lotz JM, et al. Selective breeding of Pacific white shrimp (Litopenaeus vannamei) for growth and resistance to Taura Syndrome Virus. Aquaculture. 2002;204(3-4):447-460

31. Rodriguez J, Le Moullac G. State of the art of immunological tools and health control of penaeid shrimp. Aquaculture. 2000;191(1-3): 109-119.

32. Kureshy N, Davis DA. Protein requirement for maintenance and maximum weight gain for the Pacific white shrimp, Litopenaeus vannamei. Aquaculture. 2002;204(1-2):125-143.

33. Bang W, Drake M. Acid adaptation of Vibrio vulnificus and subsequent impact on stress tolerance. Food Microbiology. 2005;22:301-309.

34. Crab R, Chielens B, Wille M, et al. The effect of different carbon sources on the nutritional value of bioflocs, a feed for Macrobrachium rosenbergii postlarvae. Aquac Res. 2010;41(4):559-567.

35. Luo G, Zhang N, Tan H, et al. Efficiency of producing bioflocs with aquaculture waste by using poly- $\beta$-hydroxybutyric acid as a carbon source in suspended growth bioreactors. Aquaculture Engineering. 2017;76:34-40

36. Ju ZY, Forster IP, Conquest L, et al. Enhanced growth effects on shrimp Litopenaeus vannamei from inclusion of whole shrimp floc or floc fractions to a formulated diet. Aquac Nutr. 2008;14:533-543.

37. Anand PSS, Kohli MPS, Kumar S, et al. Effect of dietary supplementation of biofloc on growth performance and digestive enzyme activities in Penaeus monodon. Aquaculture. 2014;418-419:108-115.

38. Bauer W, Prentice-Hernandez Cm Tesser MB, et al. Substitution of fishmeal with microbial floc meal and soy protein concentrate in diets for the Pacific white shrimp Litopenaeus vannamei. Aquaculture. 2012;342-343:112-116

39. Kheti B, Kamilya D, Choudhury J, et al. Dietary microbial floc potentiates immune response, immune relevant gene expression and disease resistance in rohu, Labeo rohita (Hamilton, 1822) fingerlings. Aquaculture. 2017;468:501-507.

40. Xu WJ, Pan LQ. Effects of bioflocs on growth performance, digestive enzyme activity and body composition of juvenile Litopenaeus vannamei in zero-water exchange tanks manipulating $\mathrm{C} / \mathrm{N}$ ratio in feed. Aquaculture. 2012;356-357:147-152. 